\title{
Chapter 17 \\ Inclusion of Interdisciplinary Approach in the Mathematics Education of Biology Trainee Teachers in Slovakia
}

\author{
Ivana Boboňová, Soňa Čeretková, Anna Tirpáková \\ and Dagmar Markechová
}

\begin{abstract}
In order to eliminate the lack of teaching materials relevant to interdisciplinary teacher education, we implemented a worksheet about human blood. Altogether 64 students of bachelor and master study programmes of biology teacher training at Constantine the Philosopher University (CPU) in Nitra, Slovakia, filled in a 12-item worksheet which required the application of mathematical methods for answering biology-related questions. Moreover, students were asked to fill out a questionnaire regarding their attitudes to this material. By means of a content analysis of the teacher trainees' performance on each of the 12 items, their current mathematical competencies (unit conversion, calculation of percentages, the rule of three, and combinatorics) were evaluated. Based on the statistical evaluation we conclude that the students' success rate in tasks focused on unit conversion, calculation of percentages, and the rule of three, was significantly different than in tasks focused on combinatorics. This suggests that the higher knowledge shown in Mendelian concepts (combinatorics) is probably based on studying it in an interdisciplinary manner in their general biology courses. Finally, we conclude that the analysis of feedback received from students provides the university educators with the opportunity to adjust the content of the worksheet, and to improve their teaching strategies, in interdisciplinary contexts.
\end{abstract}

Keywords Interdisciplinarity $\cdot$ Mathematics $\cdot$ Biology $\cdot$ Teacher trainees • Mathematical competence

I. Boboňová $(\bowtie) \cdot$ S. Čeretková · A. Tirpáková · D. Markechová Constantine the Philosopher University, Nitra, Slovakia

e-mail: ibobonova@ukf.sk

S. Čeretková

e-mail: sceretkova@ukf.sk

A. Tirpáková

e-mail: atirpakova@ukf.sk

D. Markechová

e-mail: dmarkechova@ukf.sk

(C) The Author(s) 2019

B. Doig et al. (eds.), Interdisciplinary Mathematics Education,

ICME-13 Monographs, https://doi.org/10.1007/978-3-030-11066-6_17 


\subsection{Introduction}

Over the past several years, an increasing enthusiasm has been observed for teaching approaches that combine mathematics and biology. Many researchers have discussed the need for increasing interdisciplinary teaching of these disciplines (Bialek \& Botstein, 2004; Brent, 2004; Gross, Brent, \& Hoy, 2004; May, 2004; Pevzner \& Shamir, 2009; Pursell, 2009; Steitz, 2003; Tra \& Evans, 2010). Consequently, the call for integrating more quantitative work in biology education has led to the production of new teaching tools that improve quantitative skills. Different strategies have been proposed that educators, and institutions, could use to increase the mathematical competence of biology students. These strategies include a greater integration of mathematical problems into science classes (Hester, Buxner, Elfring, \& Nagy, 2014; Hodgson et al., 2005; National Research Council [henceforth NRC], 2003), more frequent use of biological context in traditional mathematics courses (NRC, 2003; Robeva \& Laubenbacher, 2009), and the development of biology textbooks that include quantitative problems, or computational exercises (Jungck, 2005; Madlung, Bremer, Himelblau, \& Tullis, 2011).

Despite the prevalence of the subject-centred curriculum in Slovak public secondary schools, in the last decade, interdisciplinary approaches have been implemented, also, in secondary education in Slovakia, especially through several regional, as well as international, educational and research projects, such as Compass, DynaMat, Primas, and recently EU LLP Comenius project MaT ${ }^{2} \mathrm{SMc}$ (Čeretková, Jakab, \& Naštická, 2015; Melušová, Šunderlík, \& Čeretková, 2012; Pavlovičová, Rumanová, \& Švecová, 2013; Sandanusová, 2006; Ulovec, Čeretková, Dockerty, Molnár, \& Spagnolo, 2009). However, there has been no significant progress in incorporating interdisciplinary approaches into teacher education curricula at universities in Slovakia. In other words, although considerable amount of attention has been paid to an interdisciplinary approach in secondary education, the institutional education of future teachers lacks a particular focus on interdisciplinary issues.

Teaching through such a new interdisciplinary perspective requires appropriate adjustments to approaches and pedagogies (Jungck, Gaff, Fagen, \& Labov, 2010; NRC, 2003, 2008). In order to ensure the sustainable success of such interdisciplinary work, it is important to make mathematical approaches an integral component of biology teacher education at universities. Since teachers are one of the most important factors in primary, and secondary, education (Kalin \& Zuljan, 2007; Šorgo, 2010), any new trend should be introduced, most importantly, to teachers, who, consequently, can be expected to pass their general, and interdisciplinary knowledge, and skills, to students. Moreover, the beginning of a teaching career is in some ways the period that is associated with a certain shock, because the teacher trainee, who used to receive mostly theoretical training for the profession, becomes a teacher, who is exposed to a variety of educational situations every day. The basis of the pedagogical skills of a novice teacher is their experience: from these experiences a novice teacher chooses to use the situation that occurs in practice (Viteckova et al., 2016). Thus, the safest way to achieve success in interlinking a certain couple of disciplines, e.g. biology and 
mathematics, it seems that the proper development, of the professional development of pedagogical mathematical and biological content knowledge in the pre-service education of future teachers, should be based on effective teaching practice centred on active interdisciplinary learning techniques.

Based on these facts, the present study aims (1) to develop modern teaching material for biology teacher trainees, with respect to the interdisciplinarity of mathematics and biology, in use in the educational processes at Constantine the Philosopher University in Nitra, Slovakia (henceforth CPU), (2) to analyse the key mathematical competencies of biology teacher trainees with respect to the requirements of modern biology education, and (3) to receive valuable, and authentic, feedback from teacher trainees to help university educators identify the areas of strengths, and weaknesses, of the applied worksheet, in order to improve this interdisciplinary teaching material.

\subsection{Methods and Instruments}

\subsubsection{Development of Teaching Material}

Looking through the existing teaching and learning materials in Slovakia, we soon discovered that these materials were designed mostly by biology, or mathematics educators, and that they did not offer active support, or sufficient opportunities, for collaboration. Being an interdisciplinary team of mathematics and biology teacher educators, we set out to improve the situation. In order to eliminate the lack of teaching materials, relevant to interdisciplinary teacher education, we implemented a material about human blood for biology teacher trainees, with respect to the interdisciplinarity of mathematics and biology, with the perspective of further use in educational process at CPU. The developed material contains the lesson description, and a 12-item worksheet, that requires application of mathematical methods (unit conversion, calculation of percentages, the rule of three, and combinatorics) for answering biology-related questions at the secondary school level.

Following Choi and Pak (2006), Stock and Burton (2011), and Williams et al. (2016), we recognize various levels of the term interdisciplinarity which, we use in its broadest sense.

First, multi-disciplinarity is characterized as the least integrative from all integrated approaches yet, equally, it is arguably the most attainable. Multi-disciplinarity draws on knowledge from several disciplines, but stays within the boundaries of those fields. There is no attempt to cross boundaries, or generate new integrative knowledge. For example, mathematics can be utilized in other subjects for the benefit of learning mathematics, or for the benefit of learning the other subject, using mathematics as a tool, or a generalisation. The connection between subjects can be a common element between them, such as the use of length units in mathematics and biology (Fig. 17.1). 
Second, interdisciplinarity, in its narrow sense, involves the interaction between two, or more, (different) disciplines, and occurs at the interface between the disciplines. This may range from the sharing of ideas, to full integration of concepts, methodology, procedures, theory, terminology, data, and organization of research (Fig. 17.2).

Third, trans-disciplinarity is probably the most desirable, and yet difficult, to obtain form of integrated approach. Trans-disciplinarity is a specific form of interdisciplinarity in which boundaries between, and beyond, disciplines are transcended, and knowledge and perspectives from different scientific disciplines, as well as non-scientific sources, are integrated (new disciplines and theories are synthesized). Trans-disciplinary approaches can be exemplified in Mendel's laws of inheritance, which are based on mathematical probability and combinatorics (Fig. 17.3).

As shown in the examples above, (Figs. 17.1, 17.2 and 17.3) the analysed teaching material for biology teacher trainees, comprised tasks with various levels of interdisciplinarity (in the broad sense). In some of the tasks, the relation of biology and mathematics was rather loose (Fig. 17.1), which we consider to be a case of multi-disciplinarity. In other tasks, the connection of the two disciplines is obvi-

A typical human erythrocyte has a biconcave shape with disc diameter approximately $7.5 \mu \mathrm{m}$ and a thickness at the thickest point $2.1 \mu \mathrm{m}$ and a minimum thickness in the centre $1 \mu \mathrm{m}$, being much smaller than most human cells.

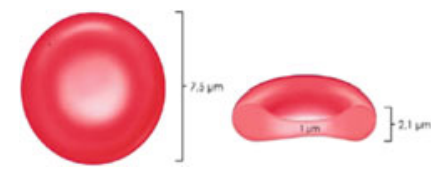

Task 1: Convert the length values of erythrocyte from micrometres to the most commonly used units of length, millimetres and metres.

Fig. 17.1 Size of erythrocyte

Erythrocyte has a biconcave shape and an average volume of about 90 femtolitres with a surface of about 136 square micrometres.

Task 2: Calculate, as a percentage, how much the surface area of the biconcave shape of erythrocytes is bigger than hypothetical spherical cells having the same volume. Why is it important to consider the surface area of erythrocytes?

Fig. 17.2 Geometric properties of erythrocyte

Task 3: Parents have four children. Is it possible that each child has different $A B O$ blood type? Explain.

Fig. 17.3 ABO blood-group genetics 
ously closer (Fig. 17.2), which we refer to as interdisciplinarity in a narrow sense. In trans-disciplinary issues, the gap between the disciplines diminishes, and the relation between them is very tight (Fig. 17.3).

\subsubsection{Mathematical Competencies Assessment}

Biology teacher trainees at CPU have a very diverse set of mathematical competencies from their previous secondary education. Moreover, they are not required to take mathematical courses during their study at the university, unless their second major is mathematics. ${ }^{1}$ Therefore, the study described in this paper, aims at assessing the mathematical competencies of university students intending to become biology teachers. Altogether 64 students, of bachelor and master study programmes of biology teacher training at CPU, filled in a 12-item worksheet, that required application of mathematical methods (unit conversion, calculation of percentages, the rule of three, and combinatorics) for answering biology-related questions. None of the biology teacher trainees studied mathematics as their second major. Teacher trainees could obtain scores ranging from 1 to 5 for each of the items, where $1=$ excellent; $2=$ very good; $3=$ good; $4=$ fair and $5=$ poor. Students' answers were evaluated statistically, which allowed determination and comparison of the rates of students' success. A non-parametric Friedman test was conducted to evaluate if there was any significant difference between the average scores achieved by biology teacher trainees in their solutions with respect to the four mathematical methods required by the tasks. Once a significant difference was found, a Neményi test was performed to find where the difference actually occurs (Anděl, 2003). The software STATISTICA was used for the data analysis, and all the tests were done at a significance level of 0.05 .

\subsubsection{Feedback Obtained in Questionnaire Survey}

After the interdisciplinary worksheet implementation, participants were asked to fill in an anonymous questionnaire regarding their attitudes to the implemented teaching material. Teacher trainees were asked to evaluate the theoretical biology introduction and parts of the practical computational exercises. By means of a 5-point Likert scale they expressed the level of their agreement with five statements regarding the following areas: comprehensibility, interest, curricular requirements, teachers' practical requirements, and collaboration of teachers. In addition, teacher trainees were asked about their personal opinion of this material. The data obtained were summarized by means of descriptive statistics.

\footnotetext{
${ }^{1}$ In Slovakia, teacher trainees, for secondary education, study two majors simultaneously.
} 


\subsection{Results and Discussion}

\subsubsection{Worksheet About Human Blood}

Traditionally, life sciences students rarely experience mathematics within the context of their majors. Indeed, anecdotal evidence suggest that students, who perceive themselves as mathematically weak, gravitate toward biology because they consider biology to be relatively mathematics free. These attitudes persist, despite mathematics course requirements for most life sciences students, because failure to integrate mathematics in meaningful ways for life sciences majors, contributes to the perception that mathematics is irrelevant outside itself (Zan, Brown, Evans, \& Hannula, 2006). Thus, in the minds of many biology students, mathematics and biology remain in two distinct, separate compartments (Hester et al., 2014).

If students, who opt for biology because they envision a science career, but "don't like maths," they are pre-selecting to ignore mathematics. Adding a mathematical subject, or two, taught by mathematics experts to the university biology curriculum is very unlikely to bring about any positive changes, because such an approach would not help students discover the interdisciplinary connections by themselves (Ortiz, 2006; Šorgo, 2010). Increasing the quantitative thinking that teacher trainees encounter in their biology courses seems to be a more effective way to challenge this perception, and encourage the transfer of mathematical skills, compared to increasing traditional mathematics requirements for biology students alone (Hester et al., 2014). Therefore, some overlap ought to be found at the content level, and in teacher education. Mathematical-biology or biological-mathematics content knowledge for all teachers should be established (Šorgo, 2010).

An appropriate model, for re-working, turns out to be the model of pedagogical content knowledge proposed by Shulman $(1986,1987)$, upgraded to technological pedagogical content knowledge by Mishra and Koehler (2006), and used in cell biology by Usak (2009). The most important part of the model to be considered, is its central section referred to as Pedagogical Biological Mathematical Content Knowledge. In order to succeed in inter-linking these disciplines, it is inevitable to reform the general approach to the professional development of prospective biology teachers in terms of their pedagogical mathematical-biological content knowledge (Šorgo, 2010).

Therefore, we designed interdisciplinary material in which we targetted quantitative skills, that we identified as supporting the biological concepts taught in the course, and being generally useful to teacher trainees throughout their progress in advanced biology courses, and further teacher career. Table 17.1 categorizes each item by the biological concept and required mathematical competence.

Identifying biological learning outcomes of the material was relatively straightforward. Establishing quantitative learning outcomes of the worksheet required more consideration. When choosing an appropriate set of mathematical skills to be included in the material, we focused on the skills that students are expected to develop, by fulfilling their mathematical pre-requisites for the course, and integrate naturally 
Table 17.1 Worksheet about human blood

\begin{tabular}{|c|c|c|c|c|c|}
\hline Task & $\begin{array}{l}\text { Biological } \\
\text { content }\end{array}$ & $\begin{array}{l}\text { Mathematical } \\
\text { content }\end{array}$ & \multicolumn{3}{|c|}{ Task examples } \\
\hline 1 & $\begin{array}{l}\text { Size of } \\
\text { erythrocytes }\end{array}$ & $\begin{array}{l}\text { Unit } \\
\text { Conversion }\end{array}$ & \multicolumn{3}{|c|}{$\begin{array}{l}\text { Typical human erythrocyte has a biconcave shape } \\
\text { with disc diameter approximately } 7.5 \mu \mathrm{m} \text { and a } \\
\text { thickness at the thickest point } 2.1 \mu \mathrm{m} \text { and a } \\
\text { minimum thickness in the centre } 1 \mu \mathrm{m} \text {, being much } \\
\text { smaller than most of other human cells } \\
\text { Task 1: Convert the length values of erythrocyte } \\
\text { from micrometres to the most commonly used units } \\
\text { of length, millimetres and metres }\end{array}$} \\
\hline 2 & $\begin{array}{l}\text { Volume of } \\
\text { erythrocytes }\end{array}$ & $\begin{array}{l}\text { Unit } \\
\text { Conversion }\end{array}$ & \multicolumn{3}{|c|}{$\begin{array}{l}\text { Scientists use special units for measuring size of } \\
\text { very small particles of human blood. For example: } \\
\text { Volume of an erythrocyte is measured in } \\
\text { femtoliters (fl) } \\
\text { Task 2: Volume of an erythrocyte is around } 90 \mathrm{fl} \text {. } \\
\text { Convert the volume of erythrocyte from } \mathrm{fl} \text { to } \mathrm{ml} \text { (use } \\
\text { SI units table) }\end{array}$} \\
\hline \multirow[t]{5}{*}{3} & \multirow[t]{5}{*}{$\begin{array}{l}\text { Blood volume } \\
\text { of erythrocytes }\end{array}$} & \multirow[t]{5}{*}{$\begin{array}{l}\text { Unit } \\
\text { conversion }\end{array}$} & \multicolumn{3}{|c|}{$\begin{array}{l}\text { Number of erythrocytes is calculated from blood } \\
\text { sample. Laboratory technicians count how many } \\
\text { erythrocytes are in one } \mathrm{mm}^{3} \text { of blood or in one litre } \\
\text { of blood. Table shows optimal amount of } \\
\text { erythrocytes in } 1 \mathrm{~mm}^{3} \text { of blood }\end{array}$} \\
\hline & & & & $\begin{array}{l}\text { Number of } \\
\text { erythrocytes in } \\
1 \mathrm{~mm}^{3}\end{array}$ & $\begin{array}{l}\text { Number of } \\
\text { erythrocytes in } \\
1 \text { litre }\end{array}$ \\
\hline & & & Men & $\begin{array}{l}4.2 \times 10^{6}-5.9 \\
\times 10^{6}\end{array}$ & \\
\hline & & & Women & $\begin{array}{l}3.8 \times 10^{6}-5.2 \\
\times 10^{6}\end{array}$ & \\
\hline & & & \multicolumn{3}{|c|}{$\begin{array}{l}\text { Task 3: Calculate the values of erythrocytes in } 1 \\
\text { litre of blood, and fill in the table }\end{array}$} \\
\hline
\end{tabular}


Table 17.1 (continued)

\begin{tabular}{|c|c|c|c|}
\hline Task & $\begin{array}{l}\text { Biological } \\
\text { content }\end{array}$ & $\begin{array}{l}\text { Mathematical } \\
\text { content }\end{array}$ & Task examples \\
\hline 4 & $\begin{array}{l}\text { Geometric } \\
\text { properties of } \\
\text { erythrocytes }\end{array}$ & Percentages & $\begin{array}{l}\text { Erythrocyte has biconcave shape and an average } \\
\text { volume of about } 90 \mathrm{fl} \text { with a surface of about } 136 \\
\text { square micrometres } \\
\text { Task 4: Calculate as a percentage, how much the } \\
\text { surface area of the biconcave shape of erythrocytes } \\
\text { is bigger than hypothetical spherical cells having } \\
\text { the same volume. Why is it important to consider } \\
\text { the surface area of erythrocytes? }\end{array}$ \\
\hline 5 & $\begin{array}{l}\text { Erythrocyte } \\
\text { deformability }\end{array}$ & Percentages & $\begin{array}{l}\text { The erythrocyte is a cell and its surface is called the } \\
\text { cell membrane. Imagine that the biconcave shape } \\
\text { of the erythrocyte changes into a sphere, while area } \\
\text { of the cell membrane remains the same. The } \\
\text { volume of such sphere would increase to } 150 \mathrm{fl} \\
\text { Task 5: Calculate in percentage, how much the } \\
\text { volume of erythrocyte increases if its shape } \\
\text { changed to a sphere }\end{array}$ \\
\hline 6 & $\begin{array}{l}\text { Haemoglobin in } \\
\text { erythrocytes }\end{array}$ & Percentages & $\begin{array}{l}\text { All haemoglobin molecules in one erythrocyte } \\
\text { weigh together } 32 \pm 2 \mathrm{pg} \text {, which is around } 34 \% \text { of } \\
\text { the erythrocyte weight } \\
\text { Task 6: What is the weight of an erythrocyte, if ( } 32 \\
\pm 2 \text { ) pg is } 34 \% \text { of its weight? }\end{array}$ \\
\hline 7 & $\begin{array}{l}\text { Volume of } \\
\text { haemoglobin in } \\
\text { human body }\end{array}$ & Rule of three & $\begin{array}{l}\text { Total number of erythrocytes in adult human body } \\
\text { is usually between } 2.10^{13} \text { and } 3.10^{13} \text { and one } \\
\text { erythrocyte contains around } 265 \times 10^{12} \\
\text { haemoglobin molecules. Haemoglobin is not } \\
\text { contained in any other cell in a human body } \\
\text { Task 7: How many haemoglobin molecules are } \\
\text { there in a human body? }\end{array}$ \\
\hline 8 & $\begin{array}{l}\text { The erythrocyte } \\
\text { life cycle }\end{array}$ & Rule of three & $\begin{array}{l}\text { When erythrocyte gets old, it dies. In one minute } \\
\text { around one million of erythrocytes die in human } \\
\text { body. But do not worry, new cells are produced } \\
\text { continuously and body keeps the number of } \\
\text { erythrocytes within the range } \\
\text { Task 8: If erythrocytes did not regenerate, in what } \\
\text { time would all erythrocytes in body die? }\end{array}$ \\
\hline 9 & $\begin{array}{l}\text { Volume of iron } \\
\text { in erythrocytes }\end{array}$ & Rule of three & $\begin{array}{l}\text { Erythrocyte attaches to oxygen thanks to iron } \\
\text { which is a constituent of haemoglobin. One gram } \\
\text { of haemoglobin contains } 3.34 \mathrm{mg} \text { of iron } \\
\text { Task 9: Calculate how many grams of iron are } \\
\text { there in all erythrocytes in adult human body }\end{array}$ \\
\hline
\end{tabular}


Table 17.1 (continued)

\begin{tabular}{|c|c|c|c|}
\hline Task & $\begin{array}{l}\text { Biological } \\
\text { content }\end{array}$ & $\begin{array}{l}\text { Mathematical } \\
\text { content }\end{array}$ & Task examples \\
\hline 10 & $\begin{array}{l}A B O \\
\text { blood-group } \\
\text { genetics }\end{array}$ & Combinatorics & $\begin{array}{l}\text { Task 10: Parents have four children. Is it possible } \\
\text { that each child has different } A B O \text { blood type? } \\
\text { Explain }\end{array}$ \\
\hline 11 & $\begin{array}{l}\text { RH } \\
\text { blood-group } \\
\text { genetics }\end{array}$ & Combinatorics & $\begin{array}{l}\text { Task 11: Is it possible that Rh-positive parents } \\
\text { have Rh-negative child? Explain }\end{array}$ \\
\hline 12 & $\begin{array}{l}\text { Blood-group } \\
\text { ABO } \\
\text { genotyping in } \\
\text { paternity testing }\end{array}$ & Combinatorics & $\begin{array}{l}\text { Task 12: A Mother with blood type B has a child } \\
\text { with blood type A. Write down all possibilities of } \\
\text { blood type which do not eliminate a man from } \\
\text { paternity test }\end{array}$ \\
\hline
\end{tabular}

into biology materials. Our motivation, for these two criteria, was that we wished to build quantitative learning outcomes that would be accessible to the biology teacher trainees, and that would support the biological learning outcomes, instead of being distracting and artificial.

Standard biology syllabi in Slovakia seldom make connections between biology and mathematics, and even those rare inter-links are just elementary. According to the biology curriculum, a successful biology teacher only needs to know how to calculate probabilities in Mendelian genetics (National Institute for Education, 2009). However, we identified other basic quantitative skills, namely unit conversion, calculation of percentages, and the rule of three. Once we had identified these skills, we discussed them with other experienced educators at CPU and project $\mathrm{MaT}^{2} \mathrm{SMc}$ partner universities from abroad, interested in the integration of mathematics and biology. The university educators affirmed that they also consider it reasonable to expect teacher trainees to apply the skills we had identified. In addition, the educators expressed their disappointment caused by the teacher trainees' inability to do so in the contexts of their biology courses.

Consequently, the final version of the worksheet about human blood consisted of 12 items requiring four mathematical methods-unit conversion, calculation of percentages, the rule of three, and combinatorics (each of the methods required in three worksheet items)-implemented in biological context with respect to the secondary school curriculum. Our approach required no fundamental changes to the curriculum, and none of the pedagogical strategies used are revolutionary. We incorporated the application of 11 quantitative skills in the existing curriculum, and based the course design on recognized effective teaching practices eliciting active learning. 


\subsubsection{Mathematical Competence Assessment}

The worksheet related to human blood consisted of items testing students' understanding of biology concepts, and their ability to apply mathematical skills in biological contexts. By means of content analysis of the teacher trainees' performance in each of the 12 items, their current mathematical competencies (unit conversion, calculation of percentages, the rule of three, and combinatorics) were evaluated (Table 17.2).

Apparently, the teacher trainees' scores vary with respect to the mathematical skills required by the tasks. In order to verify the significance of the differences, several statistical tests were conducted. First, since the assumption of normal distribution was not fulfilled, the non-parametric Friedman test was carried out. The calculated $p$ value was $p<0.05$, thus the null hypothesis $H_{0}$ : The differences between the average scores with respect to the mathematical skills required by the tasks are not significant was rejected at the 0.05 significance level. In other words, the differences between the biology teacher trainees' scores with respect to the mathematical skills required by the tasks are statistically significant (Table 17.3; Fig. 17.4).

Secondly, the Neményi method, of multiple comparisons, was performed to find where the differences actually occur (Table 17.4), i.e. in which pairs of the four mathematical skills.

The items with the highest incorrect answer rate (Table 17.3) were focussed on the application of the rule of three. The students' success rates were different significantly in these tasks than in tasks focussed on unit conversion. The students' success rates in tasks focussed on combinatorics differ significantly from tasks focussed on unit conversion, calculation of percentages, and the rule of three.

Table 17.2 Students' average scores in the mathematical tasks

\begin{tabular}{l|l|l}
\hline Task & Task score $^{\mathrm{a}}$ & Skill score \\
\hline 1 & 1.59 & 2.490 \\
\hline 2 & 2.94 & \\
\hline 3 & 2.94 & \\
\hline 4 & 1.34 & \\
\cline { 1 - 2 } 5 & 3.94 & \\
\hline 6 & 2.28 & \multirow{2}{*}{2.96} \\
\hline 7 & 2.06 & \\
\hline 8 & 2.97 & \\
\hline 9 & 3.69 & \\
\cline { 1 - 2 } 10 & 1.25 & \\
\cline { 1 - 2 } 11 & 1.72 & \\
\hline 12 & 2.03 & \\
\hline
\end{tabular}

${ }^{\mathrm{a}} 1=$ excellent; $2=$ very good; $3=$ good $4=$ fair and $5=$ poor 
Based on our own experience, and informal evidence from other biology lecturers, however, we questioned whether students were truly proficient at applying the required set of mathematical skills. By looking at teacher trainees' performance in each of 9 items focussed on unit conversion, calculation of percentages, and the rule of three (average rating 2.49-2.91), we conclude that their performance supported the assumption that students were unable to apply quantitative skills in the context of biology at the required level. This finding is consistent with the results of other researchers as it is widely recognized that students have difficulties when expected to transfer, spontaneously, skills to novel contexts (NRC, 2000), and that students in other fields are not able to transfer even relatively simple mathematical skills to new contexts (Britton, 2006). This result also supports earlier observations by Hester et al. (2014) that students perform significantly lower in tasks requiring application of mathematical skills to biological problems, than in context-free use of the same mathematical skills.

Most mathematics courses do not make a connection between mathematical concepts and applications to other fields of science (Robeva \& Laubenbacher, 2009). Our observations underscore the need for interaction and collaboration to provide new alternatives to traditional mathematics and biology courses. It has been shown that a

Table 17.3 Friedman test results

\begin{tabular}{l|l|l|l|l}
\hline & Rank sums & Mean ranks & Average score & Average score SD \\
\hline Unit conversion & 157.00 & 2.45 & 2.49 & 1.43 \\
\hline Percentages & 171.00 & 2.67 & 2.52 & 0.87 \\
\hline Rule of three & 200.00 & 3.13 & 2.91 & 1.16 \\
\hline Combinatorics & 112.00 & 1.75 & 1.67 & 0.66 \\
\hline
\end{tabular}

Test criterion value $\mathrm{Q}=39.42 ; p<0.05$

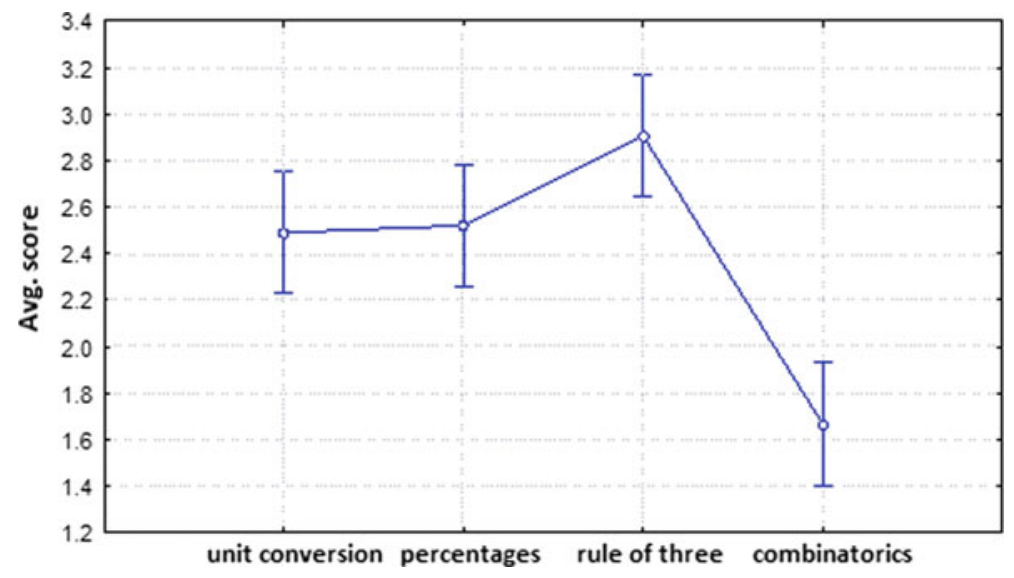

Fig. 17.4 Teacher trainees' average scores with respect to the mathematical skill 
Table 17.4 Neményi test results

\begin{tabular}{l|l}
\hline Unit conversion-Percentages & 14.00 \\
\hline Unit conversion-Rule of three & $\mathbf{4 3 . 0 0}^{\text {a }}$ \\
\hline Unit conversion-Combinatorics & $\mathbf{4 5 . 0 0}^{\text {a }}$ \\
\hline Percentages-Rule of three & 29.00 \\
\hline Percentages-Combinatorics & $\mathbf{5 9 . 0 0}^{\text {a }}$ \\
\hline Rule of three-Combinatorics & $\mathbf{8 8 . 0 0}^{\text {a }}$ \\
\hline $\begin{array}{l}\text { aAt a significance level of } 0.05 \text { the critical value is } 37.49 . \text { Values exceeding the critical value indicate } \\
\text { significant differences occurring in the compared pair(s) of mathematical skills required by the tasks }\end{array}$
\end{tabular}

course integrating mathematics and biology concepts does not hinder student learning in either of the two content areas, but rather, enhances interdisciplinary knowledge (Madlung et al., 2011). Thus, we suggest that lecturers in mathematics and biology courses, convene to discuss these issues together. Such collaboration could lead to new mathematics courses, or supplementary instruction, involving biological examples in calculus and statistics courses. This can be done by sharing research data and, or, discussing interdisciplinary papers dealing with computational biology, and planning effective ways to present this information in their classes (Robeva, Davies, Hodge, \& Enyedi, 2010; Watkins, 2010). In addition, lecturers can consider using, or modifying, the activities and materials developed within international projects, such as Compass, DynaMat, Primas, etc. (Čeretková, Jakab, \& Naštická, 2015; Melušová et al., 2012; Pavlovičová, Rumanová, \& Švecová, 2013; Sandanusová, 2006; Ulovec et al., 2009). The fact that students take mathematics requirements at different points in the curriculum, and come to biology courses with very diverse quantitative skills, is yet another challenge. To rectify this, we recommend that faculty members, in biology departments, re-evaluate the arrangement of the undergraduate curriculum, so that students take calculus and basic statistics during their first year of bachelor study. In this manner, they can move on to higher-level courses, such as genetics, microbiology, botany, zoology, and anthropology, with basic concepts that would allow them to apply mathematical tools in processing data obtained in laboratories, the interpretation of graphics, and improve their understanding of modern scientific theory. In accordance with our previous assumptions the students' success rates in tasks focussed on combinatorics were significantly different from tasks focused on unit conversion, calculation of percentages and the rule of three. Students achieved significantly better scores in these tasks focussed on combinatorics. Similarly, ColonBerlingeri and Burrowes (2011) observed the best mathematics knowledge performance of biology students by looking at their performance on items measured basic probability, probability applied to genetics, and data interpretation relevant to the topics of Mendelian genetics, population genetics, and quantitative genetics. Authors (Colon-Berlingeri \& Burrowes, 2011) suggest that the demonstrated mathematical knowledge in Mendelian concept may result from its interdisciplinary study within general biology courses. Our results, although limited by the small size of the sample studied, are in accordance with this suggestion. 
Table 17.5 Results of the questionnaire survey

\begin{tabular}{|c|c|c|c|c|c|c|}
\hline \multicolumn{2}{|l|}{ Statement } & \multicolumn{5}{|c|}{ Likert 5-point scale ${ }^{\mathrm{a}}$} \\
\hline & & \multirow{2}{*}{$\begin{array}{l}1 \\
0\end{array}$} & \multirow{2}{*}{$\begin{array}{l}2 \\
7\end{array}$} & \multirow{2}{*}{32} & \multirow{2}{*}{\begin{tabular}{|l|}
4 \\
22
\end{tabular}} & \multirow{2}{*}{$\begin{array}{l}5 \\
3\end{array}$} \\
\hline The worksheet content and activities are & Total & & & & & \\
\hline un & $\%$ & 0.00 & 10.94 & 50.00 & 34.30 & 4.69 \\
\hline \multirow{2}{*}{$\begin{array}{l}\text { The worksheet content and activities are } \\
\text { interesting }\end{array}$} & Total & 1 & 7 & 26 & 21 & 9 \\
\hline & $\%$ & 1.56 & 10.94 & 40.63 & 32.81 & 14.06 \\
\hline \multirow{2}{*}{$\begin{array}{l}\text { The worksheet content an activities meet the } \\
\text { curricular requirements }\end{array}$} & Total & 0 & 5 & 26 & 30 & 3 \\
\hline & $\%$ & 0.00 & 7.81 & 40.63 & 46.88 & 4.69 \\
\hline \multirow{2}{*}{$\begin{array}{l}\text { The worksheet meets teachers' practical } \\
\text { requirements for teaching of the content }\end{array}$} & Total & 1 & 7 & 21 & 24 & 11 \\
\hline & $\%$ & 1.56 & 10.94 & 32.81 & 37.50 & 17.19 \\
\hline \multirow{2}{*}{$\begin{array}{l}\text { The worksheet could be used properly for } \\
\text { collaboration of mathematics and biology } \\
\text { teachers }\end{array}$} & Total & 2 & 2 & 17 & 27 & 16 \\
\hline & $\%$ & 3.13 & 3.13 & 25.00 & 42.19 & 25.00 \\
\hline
\end{tabular}

$\mathrm{n}=64 ;{ }^{\mathrm{a}} 1$ —strongly disagree; 2 -disagree; 3 —neutral; 4-agree; 5 —strongly agree

\subsubsection{Feedback Obtained in Questionnaire Survey}

In order to receive authentic feedback from the biology teacher trainees, a questionnaire survey was carried out. The questionnaire consisted of 5 statements. The teacher trainees were asked to express the level of their agreement with the statements by means of 5-point Likert scale. The distribution of responses are summarized in Table 17.5.

The worksheet content, and activity understandability, were rated relatively low, with $50 \%$ of the respondents being neutral, and consequently, only $32.81 \%$ of students slightly agreed that worksheet content and activities were interesting. Also, nearly half of the teacher trainees agreed with the statement that the worksheet meets the curricular requirements $(46.88 \%)$, but a slightly lower percentage $(37.50 \%)$ agreed that teachers' practical requirements were met. The biology and mathematics collaboration, of content and activity, were rated very high, with slightly more than two-thirds agreeing or strongly agreeing $(67.19 \%)$.

We had high expectations at the beginning of the interdisciplinary worksheet application. However, we consider the students' ratings of the worksheet as relatively low, which indicates a need for adjustment to the students' level of mathematical education at university. The survey results suggest that students can resist learning more mathematics than required for mathematics courses, and tend to avoid the biology lecturers who incorporate mathematics into their curricula. We believe that if an intensive and continual effort was developed among the departments, such that the true interdisciplinary links between mathematics and biology are highlighted in all courses across the curriculum, the students' attitudes could gradually ameliorate.

Student comments from the final worksheet survey were constructive. Representative comments are listed below: 
- Add more maths details: maths formula where it is required, table, more illustrations, pictures, key words, blood illnesses.

- Too much mathematics, too much boring mathematics, too much difficult mathematics.

- Useful new knowledge about very small SI units (femtolitre).

- Nice example of interdisciplinary knowledge, useful for active thinking and deep knowledge and understanding.

Finally, we conclude that the analysis of feedback received from students provides the university educators with the basis for adjustments of the worksheet content and for improvements of the university educators' teaching strategies in interdisciplinary contexts.

\subsection{Conclusion}

Biology and mathematics teachers have much in common, in that they both seek to educate pupils to understand the wonder of the world around us. They both use the tools of logical thought, analysis, experimentation, and hypothesising to explore. But, too often, they see mathematics and biology as two distinct disciplines, separate from each other in objectives, methods, and classrooms. Also, all the pupils see mathematics and biology as completely different subjects, and often fail to apply lessons learned from one subject to another.

Therefore this study gives insights into continuing research regarding the assessment of the quality of biology teacher education in Slovakia, and development of educational instruments that would allow the acquisition of specific mathematical competencies necessary for future biology teachers in terms of an interdisciplinary approach. This study endeavours to bring these two allied subjects closer together. It attempts to promote, both biological and mathematical understanding, by ensuring both mathematics and biology teachers improve pupils understanding by working closely together.

Based on the findings of this study, we propose to offer an optional course to biology teacher trainees, that would cover several mathematical topics, and their applications in biology. The suggested mathematical, and related biological content, is shown in Table 17.6. We suggest that the lecturer of the course introduces the mathematical content and exemplifies its use in biology. In whole-class discussion, the teacher trainees should practise their mathematical skills while solving interdisciplinary tasks, assisted by the lecturer. As a follow-up, in pairs or small groups the teacher trainees should design similar interdisciplinary tasks and fit the tasks to the current primary and secondary school curriculum.

We believe that our work can serve as an example and inspiration for lecturers in different fields of biology in providing learning opportunities to bridge the gap between mathematics and biology, identifying specific areas that need to be improved, and devising alternative ways to address the gap. 
Table 17.6 Proposal of interdisciplinary mathematics course for biology teacher trainees

\begin{tabular}{l|l}
\hline Mathematical content & Biological content \\
\cline { 1 - 2 } Percentages & $\begin{array}{l}\text { General knowledge applicable in most of the } \\
\text { other areas }\end{array}$ \\
\cline { 1 - 1 } Unit conversion & Plant and animal symmetries \\
\cline { 1 - 2 } 2D and 3D shapes—-symmetries & Leaf surface, Blood volume \\
\hline 2D and 3D shapes—-surface areas and volumes \\
Number sequences (Fibonacci numbers and the & $\begin{array}{l}\text { Leaf arrangement, Number of petals in } \\
\text { flowers, Shell spirals }\end{array}$ \\
\hline Combinatorics & Mendelian inheritance \\
\hline Ratios (magnification/reduction) & Work with microscope \\
\hline Probability and elementary statistics & $\begin{array}{l}\text { Experimental work, Population curve, } \\
\text { Gaussian model, Mendelian inheritance }\end{array}$ \\
\hline Exponential and logarithmic relations & $\begin{array}{l}\text { Acidity of body fluids, Population growth } \\
\text { and decay }\end{array}$ \\
\hline
\end{tabular}

Let us finish with an important statement: Mathematics and Biology teachers do a good, and often an outstanding, job in teaching young people the basic knowledge of their respective fields! It is not the intent of this study to criticize what they do or how they do it.

However, we observed that there is hardly any collaboration, or consultancy, between mathematics and biology teachers. Mathematics teachers often use a biology context in tasks, and biology teachers often use mathematics, mathematics used with little regard towards learning. The systematic posing of questions, organizing experiments or observations, and completing, analysing, and interpreting data, are everyday challenges for biology teachers. Mathematics, on the other hand, offers a universal tool for description and evaluation, as well as for modelling, real life situations. It is indisputable that every biology teacher should possess the basic mathematical skills that are necessary for his, or her, subject, and vice versa, every mathematics teacher should perceive pieces of knowledge and information, from other sciences, as an apt motivation for stressing the usefulness of mathematics.

Therefore, we developed materials that are useful for both mathematics and biology teachers, materials that can be used in teacher training, making biology and mathematics teacher trainees aware that working together, now and in their later careers, can improve their experience and the learning of their future students. These materials are designed to increase competencies in both subjects at the same time, allowing for interdisciplinary learning and for collaboration between biology and mathematics teachers, ranging from common lesson planning to team teaching.

Thanks to these materials, students and pupils are naturally involved in the studied content, they become more open in communication, and they start to apply their biology and mathematical knowledge in a more relaxed and natural way. It is therefore right to assume that the materials are likely to help both the prospective, and 
in-service, mathematics and biology teachers to present mathematics in a realistic biology context. We believe that study of our suggested topics, and solving the related problems, will be an interesting experience for all target groups. We hope that with this study we will encourage teachers to actively seek collaboration, regardless of whether they are a biology or a mathematics teacher.

Acknowledgements This work was supported by the Slovak Research and Development Agency under the contract No. APVV-14-0446, and by the LLP/Comenius $\mathrm{MaT}^{2} \mathrm{SMc}$ project.

\section{References}

Anděl, J. (2003). Statistical methods (2nd ed.). Praha: Matfyzpress.

Bialek, W., \& Botstein, D. (2004). Introductory science and mathematics education for 21 st Century biologists. Science, 303, 788-790.

Brent, R. (2004). Points of view: The interface of mathematics and biology: Intuition and innumeracy. Cell Biology Education, 3, 88-90.

Britton, S. (2006). Are students able to transfer mathematical knowledge? In Proceedings of the 2nd International Conference on the Teaching of Mathematics. New York: Wiley. http://users. math.uoc.gr/ ictm2/Proceedings/pap267.pdf. Accessed December 12, 2016.

Čeretková, S., Jakab, I., \& Naštická, Z. (2015). PRIMAS multiplier concept implementation in Slovakian context. In K. Maaß, B. Barzel, G. Törner, D. Wernisch, E. Schäfer, \& K. ReitzKoncebovski (Eds.), Educating the educators: International approaches to scaling-up professional development in mathematics and science education (pp. 56-65). Munster: WTM.

Choi, B., \& Pak A. (2006). Multidisciplinarity, interdisciplinarity, and transdisciplinarity in health research, services, education and policy: 3 . Discipline, inter-discipline distance, and selection of discipline. Clinical \& Investigative Medicine, 29(6), 351-364.

Colon-Berlingeri, M., \& Burrowes, P. A. (2011). Teaching biology through statistics: Application of statistical methods in genetics and zoology courses. CBE-Life Sciences Education, 10, 259-267. https://doi.org/10.1187/cbe.10-11-0137.

Gross, L., Brent, R., \& Hoy, R. (2004). The interface of mathematics and biology. Cell Biology Education, 3, 85-92.

Hester, S., Buxner, S., Elfring, L., \& Nagy, L. (2014). Integrating quantitative thinking into an introductory biology course improves students' mathematical reasoning in biological contexts. CBE-Life Sciences Education, 13(1), 54-64.

Hodgson, T., Keck, R., Patterson, R., \& Maki, D. (2005). Mathematics in the biology classroom. A model of interdisciplinary education. Journal of College Science Teaching, 34, 46-50.

Jungck, J. (2005). Challenges, connection, complexities: Education for collaboration. In L. A. Steen (Ed.), Math and Bio 2010: Linking undergraduate disciplines (pp. 1-12). Washington, D.C.: The Mathematical Association of America.

Jungck, J., Gaff, H., Fagen, A., \& Labov, J. (2010). "Beyond BIO2010: Celebration and Opportunities" at the intersection of mathematics and biology. CBE-Life Sciences Education, 9, 143-147.

Kalin, J., \& Zuljan, M. (2007). Teacher perceptions of the goals of effective school reform and their own role in it. Educational Studies, 33, 163-175.

Madlung, A., Bremer, M., Himelblau, E., \& Tullis, A. (2011). A study assessing the potential of negative effects in interdisciplinary math-biology instruction. CBE-Life Sciences Education, 10, $43-54$.

May, R. (2004). Uses and abuses of mathematics in biology. Science, 303, 790-793.

Melušová, J., Šunderlík, J., \& Čeretková, S. (2012). Interdisciplinary teaching of mathematics and science in Slovakia—pilot study. Acta Mathematica, 515, 95-100. 
Mishra, P., \& Koehler, M. (2006). Technological pedagogical content knowledge: A framework for teacher knowledge. Teachers College Record, 108, 1017-1054.

National Institute for Education. (2009). State educational program-Biology (ISCED3). Bratislava: Statpedu.

National Research Council. (2000). Learning and transfer. How people learn: Brain, mind, experience, and school (Expanded ed.). Washington, D.C.: National Academies Press.

National Research Council. (2003). BIO 2010: Transforming undergraduate education for future research biologists. Washington, D.C.: National Academies Press.

National Research Council. (2008). The role of theory in advancing 21st Century biology: Catalyzing transformative research. Washington, D.C.: National Academies Press.

Ortiz, M. (2006). Numbers, neurons \& tides, Oh my! Mathematics, the forgotten tool in biology. The American Biology Teacher, 68, 458-462.

Pavlovičová, G., Rumanová, L., \& Švecová, V. (2013). Geometry in gardens and parks. In J. Novotná \& N. Mousoulides (Eds.), Bringing mathematics to earth (pp. 169-181). Nicosia: Demetra Ltd.

Pevzner, P., \& Shamir, R. (2009). Computing has changed biology-biology education must catch up. Science, 325, 541-542.

Pursell, D. (2009). Enhancing interdisciplinary, mathematics, and physical science in an undergraduate life science program through physical chemistry. CBE-Life Sciences Education, 8, 15-28.

Robeva, R., Davies, R., Hodge, T., \& Enyedi, E. (2010). Mathematical biology modules based on modern molecular biology and modern discrete mathematics. CBE-Life Sciences Education, 9, 227-240.

Robeva, R., \& Laubenbacher, R. (2009). Mathematical biology education: Beyond calculus. Science, $325,542-543$.

Sandanusová, A. (2006). Interdisciplinary relations and their application in creating the worksheets. In XXIV. International colloquium on the acquisition process management. Brno: University of Defence.

Shulman, L. (1986). Those who understand: Knowledge growth in teaching. Educational Research, $15,4-14$.

Shulman, L. (1987). Knowledge and teaching: Foundations of the new reform. The Harvard Educational Review, 57, 1-22.

Šorgo, A. (2010). Connecting biology and mathematics: First prepare the teachers. CBE-Life Sciences Education, 9(3), 196-200.

Steitz, J. (2003). Bio 2010: New challenges for biology educators. Cell Biology Education, 2, 87-91.

Stock, P., \& Burton, J. (2011). Defining terms for integrated (Multi-Inter-Trans-Disciplinary) sustainability research. Sustainability, 3, 1090-1113.

Tra, Y., \& Evans, I. (2010). Enhancing interdisciplinary mathematics and biology education: A microarray data analysis course bridging these disciplines. CBE-Life Sciences Education, 9(3), 217-226.

Ulovec, A., Čeretková, S., Dockerty, A., Molnár, J., \& Spagnolo, F. (2009). Motivating and exciting methods in mathematics and science-Case studies. Olomouc: VUP.

Usak, M. (2009). Preservice science and technology teachers' pedagogical content knowledge on cell topics. Educational Sciences: Theory \& Practice, 9, 2033-2046.

Viteckova, M., Prochazka, M., Gadusova, Z., \& Stranovska, E. (2016). Identifying novice teacher's needs-The basis for novices' targeted support. In: L. Gómez Chova, A. López Martínez, I. Candel Torres (Eds.), Proceedings of ICERI2016 Conference (pp. 7731-7738). Seville: IATED.

Watkins, J. (2010). On a calculus-based statistics course for life science students. CBE-Life Sciences Education, 9, 298-310.

Williams, J., Roth, W.-M., Swanson, D., Doig, B., Groves, S., Omuvwie, M., et al. (2016). Interdisciplinary mathematics education: State of the art. Cham: Springer. https://doi.org/10.1007/9783-319-42267-1.

Zan, R., Brown, L., Evans, J., \& Hannula, M. (2006). Affect in mathematics education: An introduction. Educational Studies in Mathematics, 63, 113-121. 
Open Access This chapter is licensed under the terms of the Creative Commons Attribution 4.0 International License (http://creativecommons.org/licenses/by/4.0/), which permits use, sharing, adaptation, distribution and reproduction in any medium or format, as long as you give appropriate credit to the original author(s) and the source, provide a link to the Creative Commons licence and indicate if changes were made.

The images or other third party material in this chapter are included in the chapter's Creative Commons licence, unless indicated otherwise in a credit line to the material. If material is not included in the chapter's Creative Commons licence and your intended use is not permitted by statutory regulation or exceeds the permitted use, you will need to obtain permission directly from the copyright holder.

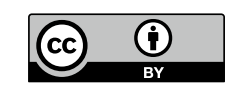

